\title{
44. LEG 75 METHODS FOR LABORATORY-MEASURED PHYSICAL PROPERTIES, GEARHART-OWEN WELL LOGS, AND THE UYEDA DOWNHOLE TEMPERATURE PROBE ${ }^{1}$
}

\author{
Robert E. Boyce, Scripps Institution of Oceanography, Deep Sea Drilling Project, La Jolla, California
}

\section{INTRODUCTION}

We measured heat conductivity, sound velocity, 2-minute GRAPE wet-bulk density, gravimetric wet-bulk density, wet-water content, and porosity on the same laboratory sample where possible.

An attempt was made to obtain an undisturbed sample. This is a serious problem in the upper $200 \mathrm{~m}$ of Hole $530 \mathrm{~A}$, where the sediments are soft, since the standard drill bit is $25 \mathrm{~cm}$ in diameter, with the $\sim 6-\mathrm{cm}$ diameter coring hole within this cutting bit. Most soft sediments are literally "squirted" into the core barrel and completely disturbed.

Because of this core disturbance, few discrete samples for physical property measurements were taken in the upper portion of Hole 530A, though the continuousanalog GRAPE was always run. Another result of the core disturbance in the upper part of the hole, and the stiffness of those samples that were not disturbed, was that vane shear strength could only be measured on a small number of "semi-soft" samples in Hole 530A. In Holes 530B, 532, and 532B, where the hydraulic piston corer was used, some of the cores (and the upper portions of many of these cores) were disturbed; thus not many samples were taken.

The criterion for selecting an undisturbed sample is the presence of undistorted bedding or laminae in the sample. The obvious problem with this criterion is that a completely homogeneous soft sediment core would not be sampled, even if it were undisturbed.

In general, sediment samples remained in the core liner for about 4 hours. The core section was split, and samples were immediately selected for heat conductivity. Following heat conductivity measurements, a D-shaped sample was cut for the sound velocity measurement, and a smear slide was made. This sample was wrapped in plastic and placed in a small plastic box with a wet sponge. It was then removed from the plastic wrapper and its surface cleaned with either a spatula or file. Distilled water was squirted on these surfaces and its velocities were measured, followed by the GRAPE 2-minute wet-bulk density determination. Afterwards, a subsample was cut for gravimetric determination of wet-water content, wet-bulk density, and porosity. This sample was cleaned, and wrapped in plastic and then sealed in a

\footnotetext{
${ }^{1}$ Hay, W. W., Sibuet, J.-C., et al., Init. Repts. DSDP, 75: Washington (U.S. Govt. Printing Office.
}

plastic vial with a wet towel. The vial was placed in a refrigerator above freezing until it could be processed.

Basalt samples were handled differently because of DSDP's official curatorial process. Basalt was not in a plastic liner; therefore, it was necessary to select sound velocity samples when the cores arrived on deck and were brought into the laboratory. We measured the velocity of the basalt when the core first arrived on deck. The velocity of the basalt was measured across the $6.6-\mathrm{cm}$ diameter of the core after filing and wetting with distilled water. These core segments were wrapped in plastic until the samples were processed by the DSDP curator and eventually split. After that core segment was split (after 4 hours in the laboratory), a mini-core ( $\sim 2 \mathrm{~cm}$ diameter) was drilled out of this half-core segment. This mini-core was wrapped in plastic and placed in a plastic vial with a damp sponge until velocity and a 2-minute GRAPE determination were made. Velocity was measured across the axis and diameter of the mini-core and 2-minute GRAPE was measured parallel to the axis of the minicore. The mini-core was then wrapped in plastic and sealed in a vial with a wet sponge and placed in a refrigerator (slightly above freezing) until its wet-bulk density, wet-water content, and porosity were gravimetrically determined.

The velocities on the whole core should be used in geophysical calculations. This method gives better and significantly higher velocities than the mini-core method. This is true because of (1) a larger sample size, which reduces the error, and (2) the fact that the sample will never be more saturated with water than at that time. The mini-core method was used in order to measure anisotropy.

\section{Heat Conductivity}

Heat conductivity measurements were not thought reliable because of the lack of a precisely known shipboard standard; thus, the data are not published here. However these data do exist in DSDP data files for future study.

\section{Acoustic Velocity}

The sample was handled as has been discussed above. Where sediments were too soft to handle, velocities were measured through a split core liner with the average linear thickness $(0.276 \mathrm{~cm})$ and travel time $(1.314 \mu \mathrm{s})$ subtracted (Table 1).

Acoustic velocity is the compressional velocity at $400 \mathrm{kHz}$ through wet-saturated geologic material, reported in units of $\mathrm{km} / \mathrm{s}$. 
Table 1. Average liner thickness and average travel time measurements, 13 August 1980.

\begin{tabular}{cc}
\hline $\begin{array}{c}\text { Liner } \\
\text { thickness } \\
(\mathrm{cm})\end{array}$ & $\begin{array}{c}\text { Liner } \\
\text { travel time } \\
(\mu \mathrm{s})\end{array}$ \\
\hline 0.260 & 1.36 \\
0.273 & 1.32 \\
0.271 & 1.27 \\
0.273 & 1.33 \\
0.268 & 1.26 \\
0.317 & 1.22 \\
0.270 & 1.32 \\
0.255 & 1.25 \\
0.274 & 1.30 \\
0.285 & 1.40 \\
0.277 & 1.34 \\
Mean $=0.276$ & Mean $=1.314$ \\
\hline
\end{tabular}

Note: These were calculated by measuring velocity through a D-shaped block and then measuring velocity through the D-shaped block plus the liner. From these two velocity data sets, the liner thickness and travel time were calculated.

Velocity was measured with a Hamilton Frame Velocimeter, which is accurate to $\pm 2 \%$. The basic equipment and technique are described in Boyce (1973); and therefore these will not be described here, except for calibration procedures with corresponding data, and sampling techniques.

\section{Oscilloscope Calibration and Velocity Correction Factors}

The oscilloscope used on Leg 75 was the Tektronix 485. The correction factors listed in Table 2 were used to calculate the sound velocity data for all holes on Leg 75 . The sound velocity correction factors are calculated by averaging numerous measurements on the lucite, brass, and aluminum semi-standards, assuming the true velocities are the Schreiber sound velocities listed in Table 3 (Boyce, 1973 and 1976). In addition, distilled water, whose acoustic velocities at given temperatures are known, is also used as a standard. Apparent velocity measurements are averaged for each semi-standard for a given $\mu \mathrm{s} / \mathrm{cm}$ setting on the oscilloscope (Tables 4-8). Deviations of the averages of apparent velocities, measured on the velocimeter, from the true velocities of the semistandards are used to calculate a set of correction fac-

Table 2. Correction factors $(\mathrm{K})$ for the DSDP Tektronics 835 oscilloscope, Leg 75 .

\begin{tabular}{cc}
\hline $\begin{array}{c}\text { Scope } \\
\text { setting } \\
(\mu \mathrm{s} / \mathrm{cm})\end{array}$ & $\mathrm{K}$ \\
\hline 1.0 & Apparent velocity $\times 1.0069=$ true velocity \\
2.0 & Apparent velocity $\times 0.9989=$ true velocity \\
5.0 & Apparent velocity $\times 0.9963=$ true velocity \\
\hline
\end{tabular}

Table 3. Predetermined sound velocities of lucite, brass and aluminum semi-standards (as listed in Boyce, 1973).

\begin{tabular}{|c|c|c|c|}
\hline & & $\begin{array}{l}\text { Sound velocity } \\
(\mathrm{km} / \mathrm{s})\end{array}$ & \\
\hline & Lucite & Brass & Aluminum \\
\hline Boyce & $\begin{array}{l}2.741 \\
( \pm 0.84 \%)\end{array}$ & $\begin{array}{l}4.506 \\
( \pm 0.45 \%)\end{array}$ & $\begin{array}{l}6.293 \\
( \pm 1.29 \%)\end{array}$ \\
\hline Schreiber ${ }^{\mathrm{a}}$ & $\begin{array}{l}2.745 \\
( \pm 0.006 \mathrm{~km} / \mathrm{s})\end{array}$ & $\begin{array}{l}4.529 \\
( \pm 0.004 \mathrm{~km} / \mathrm{s})\end{array}$ & $\begin{array}{l}6.295 \\
( \pm 0.008 \mathrm{~km} / \mathrm{s}\end{array}$ \\
\hline
\end{tabular}

a E. Schreiber, Lamont-Doherty Geological Observatory (pers. comm., 1971. Schreiber used the modified pulse-transmission method (Mattaboni and Schreiber, 1967).

Table 4. Uncorrected velocities $(\mathrm{km} / \mathrm{s})$ through aluminum sonic semistandards.

\begin{tabular}{|c|c|c|c|c|}
\hline \multirow{2}{*}{$\begin{array}{l}\text { Thickness of } \\
\text { standards } \\
\text { (cm) }\end{array}$} & \multicolumn{2}{|l|}{1.0} & \multicolumn{2}{|c|}{2.0} \\
\hline & 2.54 & 5.00 & 2.54 & 5.00 \\
\hline & $\begin{array}{l}6.223^{b} \\
6.178 \\
6.355 \\
6.325 \\
6.360 \\
6.170 \\
6.198 \\
6.303 \\
6.108 \\
6.123\end{array}$ & & $\begin{array}{l}6.350^{b} \\
6.290 \\
6.384 \\
6.433 \\
6.387 \\
6.384 \\
6.215 \\
6.384 \\
6.305\end{array}$ & $\begin{array}{l}6.234^{b} \\
6.290 \\
6.182 \\
6.328 \\
6.274 \\
6.288 \\
6.363 \\
6.328 \\
6.312 \\
6.320\end{array}$ \\
\hline Average & 6.234 & & 6.348 & 6.292 \\
\hline Range (\%) & $\begin{array}{l}+2.0 \\
-2.0\end{array}$ & & $\begin{array}{l}+1.3 \\
-2.1\end{array}$ & $\begin{array}{l}+1.1 \\
-1.7\end{array}$ \\
\hline$K^{d}$ & 1.0098 & & 0.9917 & 1.0005 \\
\hline
\end{tabular}

Note: No data are available at $5.0 \mu \mathrm{s} / \mathrm{cm}$. The best data precision occurs when entire range of $\mu \mathrm{s} / \mathrm{cm}$ delay dial is used:

a Good use: 6-10 range.

b Fair use: 3-6 range.

c Poor use: $0-3$ range.

${ }^{d} \mathrm{~K}=($ Average velocity $\times K)=$ true velocity $=6.295$ $\mathrm{km} / \mathrm{s}$.

tors $(\mathrm{K})$ for each $\mu \mathrm{s} / \mathrm{cm}$ setting on the oscilloscope as follows:

$$
\begin{gathered}
\text { Average apparent velocity }(\mathrm{K})= \\
\text { true velocity of semi-standards }
\end{gathered}
$$

\section{Vane Shear Strength}

Vane shear strength is the shearing force (g) per square area $\left(\mathrm{cm}^{2}\right)$ for wet-saturated clayey sediment. For Leg 75 data it represents primarily clayey cohesion of the material and not (theoretically) friction of the coarser grains.

Vane shear measurements were attempted on relatively undisturbed clay samples. Vane shear strength is defined as the maximum torque applied to a vane in a clayey sample before failure. Failure theoretically occurs around the cylindrical surface area of the vane, and 
Table 5. Uncorrected velocities $(\mathrm{km} / \mathrm{s})$ through brass sonic semistandards.

\begin{tabular}{|c|c|c|c|c|}
\hline \multirow{2}{*}{$\begin{array}{l}\text { Scope setting } \\
(\mu / \mathrm{cm}\end{array}$} & \multicolumn{2}{|l|}{1.0} & \multicolumn{2}{|c|}{2.0} \\
\hline & 2.54 & 5.00 & 2.54 & 5.00 \\
\hline & $4.511^{b}$ & - & $4.479^{c}$ & $4.477^{b}$ \\
\hline & 4.515 & - & 4.559 & 4.468 \\
\hline & 4.573 & - & 4.576 & 4.434 \\
\hline & 4.547 & - & 4.543 & 4.528 \\
\hline & 4.496 & - & 4.617 & 4.508 \\
\hline & 4.561 & - & 4.594 & 4.492 \\
\hline & 4.455 & - & 4.600 & 4.485 \\
\hline & 4.489 & - & 4.535 & 4.464 \\
\hline & 4.495 & - & 4.541 & 4.464 \\
\hline & 4.471 & - & 4.574 & 4.481 \\
\hline Average & 4.511 & & 4.562 & 4.477 \\
\hline Range $(\%)$ & $\begin{array}{l}+1.4 \\
-1.2\end{array}$ & & $\begin{array}{l}+1.2 \\
-1.8\end{array}$ & $\begin{array}{l}+1.1 \\
-1.0\end{array}$ \\
\hline $\mathrm{K}^{\mathrm{d}}$ & 1.0040 & & 0.9928 & 1.0116 \\
\hline
\end{tabular}

Note: No data are available at $5.0 \mu \mathrm{s} / \mathrm{cm}$. The best data precision occurs when entire range of the $\mu \mathrm{s} / \mathrm{cm}$ delay dial is used:

a Good use: 6-10 range.

b Fair use: 3-6 range.

c Poor use: $0-3$ range.

$\mathrm{d}_{\mathrm{K}}=($ Average velocity $\times \mathrm{K})=$ true velocity $=4.529$ $\mathrm{km} / \mathrm{s}$.

Table 6. Uncorrected velocities $(\mathrm{km} / \mathrm{s})$ through lucite sonic semistandards.

\begin{tabular}{|c|c|c|c|c|}
\hline \multirow{2}{*}{$\begin{array}{l}\text { Scope setting } \\
\text { Thickness of } \\
\text { standards } \\
\text { (cm) }\end{array}$} & \multicolumn{2}{|c|}{$2.0 \mu \mathrm{s} / \mathrm{cm}$} & \multicolumn{2}{|c|}{$5.0 \mu \mathrm{s} / \mathrm{cm}$} \\
\hline & 2.54 & 5.00 & 2.54 & 5.00 \\
\hline & $2.745^{\mathrm{b}}$ & & $2.808^{\mathrm{C}}$ & $2.772^{\mathrm{b}}$ \\
\hline & 2.785 & & 2.756 & 2.771 \\
\hline & 2.714 & & 2.772 & 2.787 \\
\hline & 2.768 & & 2.754 & 2.757 \\
\hline & 2.790 & & $2.904(?)$ & 2.783 \\
\hline & 2.749 & & 2.839 & 2.737 \\
\hline & 2.771 & & 2.817 & 2.724 \\
\hline & 2.787 & & 2.830 & 2.734 \\
\hline & 2.795 & & 2.822 & 2.734 \\
\hline & 2.775 & & 2.867 & 2.762 \\
\hline Average & 2.768 & & 2.817 & 2.756 \\
\hline Range (\%) & $\begin{array}{l}+1.0 \\
-2.0\end{array}$ & & $\begin{array}{l}+1.8 \\
-2.2\end{array}$ & $\begin{array}{l}+1.0 \\
-1.2\end{array}$ \\
\hline $\mathrm{K}^{\mathrm{d}}$ & 0.9917 & & 0.9744 & 0.9960 \\
\hline
\end{tabular}

Note: No data are available at $1.0 \mu \mathrm{s} / \mathrm{cm}$. The best data precision occurs when entire range of the $\mu \mathrm{s} / \mathrm{cm}$ delay dial is used:

${ }^{a}$ Good use: $6-10$ range.

b Fair use: 3-6 range.

c Poor use: $0-3$ range.

$\mathrm{d}_{\mathrm{K}}=($ Average velocity $\times \mathrm{K})=$ true velocity $=2.745$ $\mathrm{km} / \mathrm{s}$.

the final shear strength is the force $(\mathrm{g})$ per area $\left(\mathrm{cm}^{2}\right)$ of the cylindrical vane. The sample is considered to be in an undrained condition. Theoretically shear strength is made up of cohesion and frictional components, and
Table 7. Uncorrected velocities $(\mathrm{km} / \mathrm{s})$ through distilled water standards.

\begin{tabular}{ccc}
\hline Scope setting $(\mu \mathrm{s} / \mathrm{cm})$ & 2.0 & 5.0 \\
\hline Thickness of water $(\mathrm{cm})$ & $\sim 1$ & $\sim 2$ \\
\hline Temperature $\left({ }^{\circ} \mathrm{C}\right)$ & 19 & 20 \\
\hline & $1.457^{\mathrm{b} / \mathrm{c}}$ & $1.493^{\mathrm{b}}$ \\
& 1.468 & 1.487 \\
& 1.466 & 1.490 \\
& 1.473 & 1.492 \\
& 1.488 & 1.494 \\
& 1.483 & 1.493 \\
& 1.485 & 1.466 \\
& 1.476 & 1.488 \\
Average & 1.485 & \\
Range $(\%)$ & 1.487 & \\
& 1.477 & 1.488 \\
$\mathrm{~K}^{\mathrm{d}, \mathrm{e}}$ & +0.7 & +0.4 \\
& -1.4 & -1.5 \\
& 1.0020 & 0.9966 \\
\hline
\end{tabular}

Note: Velocity distilled water $\left(19^{\circ} \mathrm{C}\right)=1.480 \mathrm{~km} / \mathrm{s}$; velocity distilled water $\left(20^{\circ} \mathrm{C}\right)=1.483 \mathrm{~km} / \mathrm{s}$. The best data precision occurs when entire range of the $\mu \mathrm{s} / \mathrm{cm}$ delay dial is used:

a Good use: $6-10$ range.

b Fair use: 3-6 range.

c Poor use: 0-3 range.

$\mathrm{d}_{\mathrm{K}}$ : $($ Average velocity $\times \mathrm{K})=$ true velocity $=1.480$ $\mathrm{km} / \mathrm{s}$ at $19^{\circ} \mathrm{C}$.

${ }^{\mathrm{e}} \mathrm{K}:($ Average velocity $\times \mathrm{K})=$ true velocity $=1.483$ $\mathrm{km} / \mathrm{s}$ at $20^{\circ} \mathrm{C}$.

Table 8. Calculation of final correction factors $(\mathrm{K})$ for each $\mu \mathrm{s} / \mathrm{cm}$ setting on DSDP oscilloscope (data from Tables 4 to 7 ).

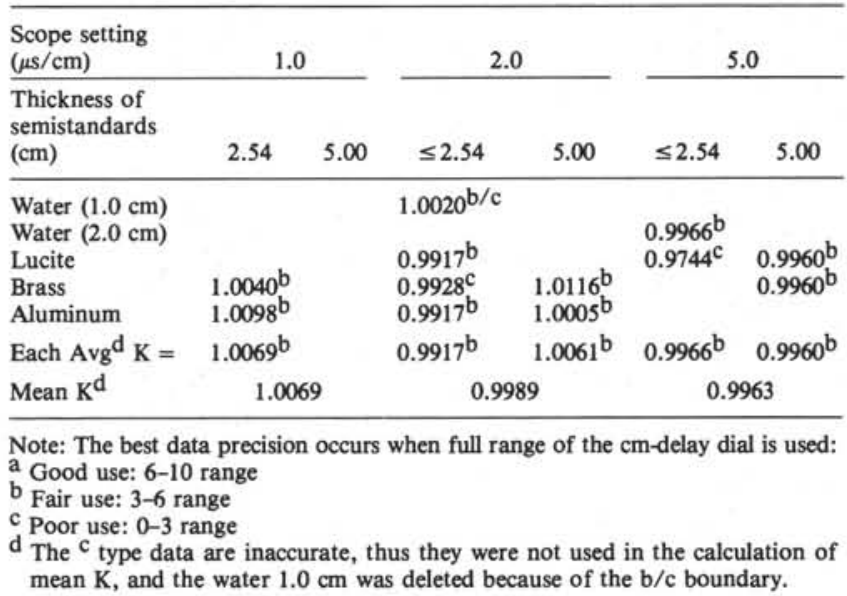

the vane shear device theoretically (though in reality not completely) measures the cohesional component of the total shear strength of the sediment.

On Leg 75, vane shear measurements were done with the DSDP Wykham Farrance laboratory vane apparatus. All of the equipment, techniques, and calibrations are in Boyce (1977) and will not be discussed further here, except for changes from Boyce (1977) and other pertinent information. The 1.263 (high) $\times 1.278$ (diameter) $\mathrm{cm}$ vane was used, and it was buried about $0.7 \mathrm{~cm}$ on top and bottom of the sample. Because it was necessary to measure the shear strength on a split core (in or- 
der to find a proper lithologic sample), the vane was inserted parallel to bedding. The remolded test was done immediately after rotating the vane ten times (while in the sample).

\section{WET-BULK DENSITY BY GRAPE TECHNIQUES}

\section{Introduction}

During Leg 75 we used the Gamma Ray Attenuation Porosity Evaluator (GRAPE) device, which was developed and described by Evans (1965) and modified as discussed by Boyce (1976). See Boyce (1976) for calibration, discussion, interpretation, precautions, and derivation of the shore-based computer calculations of the techniques used here.

\section{Analog GRAPE}

The Leg 75 analog GRAPE system did not have available the calipers; thus diameters were measured by hand. All diameter adjustments to the geometric problems discussed in Boyce (1976) have been applied. We will only present enough information here to show how, and by which equations in Boyce (1976), the data were calculated.

The analog GRAPE data includes for each core: (1) a $6.61-\mathrm{cm}$ diameter aluminum standard in liner, (2) a 2.54-cm diameter aluminum standard in liner, and (3) the geologic core in liner. These data were processed (on the ship) through Equation 15 (assuming a constant attenuation coefficient of $0.1 \mathrm{~cm}^{2} / \mathrm{g}$ and a constant thickness of $6.61 \mathrm{~cm}$ for both standards and the core sample) as in Boyce (1976). Then, at the shore-based computer facilities, the resulting data were processed through Equation 25, using the following parameters: The corrected density of the $6.61-\mathrm{cm}$ aluminum standard $\left(\varrho_{a c}\right)$ is $2.6 \mathrm{~g} / \mathrm{cm}^{3}$, and a $1.00 \mathrm{~g} / \mathrm{cm}^{3}$ density is assigned to the $2.54-\mathrm{cm}$ aluminum standard. The latter is substituted for the corrected-density $\left(\varrho_{f c}\right)$ of the water standard. The Evans (1965) "corrected" wet-bulk density $\left(\varrho_{b c}\right)$, obtained from Equation 25, is then adjusted for: (1) the diameter of the core (the investigator may obtain diameters from the core photographs or from the DSDP repository if he wishes to manipulate the data), (2) the "corrected density" of the air, water, sediment, or breccia, around the core (see Table 9), and (3) whether the diameter of the core is aligned to the gamma-ray beam (see Table 9). These geometric adjustments are applied by placing $\varrho_{b c}$ in Equations 32 through 36 of Boyce (1976). The new geometrically adjusted $\varrho_{b c}$ is processed through Equation 27, in Boyce (1976), to adjust for the anomalous $1.128 \mathrm{~g} / \mathrm{cm}^{3}$ "corrected" density of seawater. The following parameters are used in Equation 27: grain density $\left(\varrho_{g}\right)=2.7 \mathrm{~g} / \mathrm{cm}^{3}$ for sedimentary rock and $3.0 \mathrm{~g} / \mathrm{cm}^{3}$ for basalt; "corrected"'-grain density $\left(\rho_{\mathrm{gc}}\right)$ $=2.7 \mathrm{~g} / \mathrm{cm}^{3}$ for sedimentary rock and $3.0 \mathrm{~g} / \mathrm{cm}^{3}$ for basalt; fluid density $\left(\varrho_{f}\right)=1.025 \mathrm{~g} / \mathrm{cm}^{3}$; and "corrected" fluid density $\left(e_{f c}\right)=1.128 \mathrm{~g} / \mathrm{cm}^{3}$. The final wet-bulk density $\left(\varrho_{b}\right)$ derived from Equation 27 is the "true" wet-

\footnotetext{
${ }^{2}$ Beginning with Leg 70 , the analog GRAPE system now moves the cores at an increased rate of $5.71 \mathrm{~mm}$ for each two-second count.
}

bulk density ( $\pm 11 \%$ for each $3.17 \mathrm{~mm}$ length along the

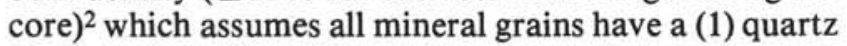
attenuation coefficient, and (2) true-, and (3) correctedgrain densities of $2.7 \mathrm{~g} / \mathrm{cm}^{3}$.

\section{Static Two-Minute GRAPE}

The static mode of the GRAPE allows individual samples to be counted for a 2-minute period with a precision of $\pm 2 \%$. These samples are labeled a "GRAPE special 2-minute count wet-bulk density."

Numerous different diameter aluminum standards were run prior to Hole 530 , and a set of $2.54-\mathrm{cm}$ and $6.61-\mathrm{cm}$ aluminum standards were processed after Hole 532B. The standards were used to calculate the apparent quartz attenuation coefficient $\left(\mu_{a}\right)$ using Equations 22 and 23 in Boyce (1976). The results of the aluminum standards, which were run prior to and after sites, are listed in Tables 10 and 11.

The data in these tables indicate that there is a significant difference in "apparent" quartz attenuation coefficents, $\mu_{\mathrm{a}}$, for different diameter standards, as discussed in Boyce (1976). Therefore, we calculate our 2-minute count GRAPE data as did Boyce (1976a) in that when we use Equation 24 (Boyce, 1976a) to calculate true density, we have to determine $\mu_{a}$ by a linear interpolation between the $6.61-\mathrm{cm}$ aluminum standard and $2.54-\mathrm{cm}$ aluminum standard, based on the thickness of the sample. We will assign a value of $0.10126 \mathrm{~cm}^{2} / \mathrm{g}$ to the $6.61-\mathrm{cm}$ aluminum standard and 0.10056 to the $2.54-\mathrm{cm}$ aluminum standard.

The 2-minute GRAPE technique and calculations used on Leg 75 are summarized as follows: For each GRAPE 2-minute count determination we measured the gamma count ( 2 minutes) through the sample, with a new gamma count ( 2 minutes) in air for each sample, and measured the sample's thickness. We then used these values in Equation 24 (Boyce, 1976) to calculate the Evans (1965) corrected wet-bulk density $\left(\varrho_{b c}\right)$ using a $\mu_{a}$ derived from a linear interpolation (as discussed in Boyce, 1976) between (1) $0.10126 \mathrm{~cm}^{2} / \mathrm{g}$ assigned to the $6.61 \mathrm{~cm}$ aluminum standard and (2) $0.10056 \mathrm{~cm}^{2} / \mathrm{g}$ assigned to the $2.54 \mathrm{~cm}$ aluminum standard. We then took this $e_{b c}$, derived from Equation 24, and placed it in Equation 21 (Boyce, 1976) to calculate "true" wet-bulk density. The following numerical data were used in Equation 21: (1) grain density $\left(\varrho_{g}\right)=2.7 \mathrm{~g} / \mathrm{cm}^{3}$ for sedimentary rock and $3.0 \mathrm{~g} / \mathrm{cm}^{3}$ for basalt; (2) corrected grain density $\left(\varrho_{g c}\right)$ $=2.7 \mathrm{~g} / \mathrm{cm}^{3}$ for sedimentary rock and $3.0 \mathrm{~g} / \mathrm{cm}^{3}$ for basalt; (3) fluid density $\left(e_{f}\right)=1.025 \mathrm{~g} / \mathrm{cm}^{3}$; and (4) corrected fluid density $\left(\varrho_{f c}\right)=1.128 \mathrm{~g} / \mathrm{cm}^{3}$. This final "true" wet-bulk density derived from Equation 21 is the value published in this volume. See Boyce (1976) for discussions of errors and assumptions of these formulas.

The GRAPE data assume that the sediments and rocks have a $35 \%$ interstitial water salinity.

\section{GRAVIMETRIC WET-BULK DENSITY, WET-WATER CONTENT, AND POROSITY}

On the Glomar Challenger 10 to $30 \mathrm{~g}$ samples were processed by the shipboard technicians to determine gravimetrically the wet-bulk density, wet-water content, and porosity. 
Table 9. Geometric condition of Leg 75 cores as they were processed through the analog GRAPE.

\begin{tabular}{|c|c|c|c|c|c|}
\hline $\begin{array}{l}\text { Core-Section } \\
\text { (interval in } \mathrm{cm} \text { ) }\end{array}$ & $\begin{array}{l}\text { Geometric } \\
\text { condition }^{\mathrm{a}}\end{array}$ & $\begin{array}{c}\text { Core-Section } \\
\text { (interval in } \mathrm{cm} \text { ) }\end{array}$ & $\begin{array}{l}\text { Geometric } \\
\text { condition }^{\mathrm{a}}\end{array}$ & $\begin{array}{l}\text { Core-Section } \\
\text { (interval in } \mathrm{cm} \text { ) }\end{array}$ & $\begin{array}{l}\text { Geometric } \\
\text { condition }^{2}\end{array}$ \\
\hline \multicolumn{2}{|l|}{ Hole 530} & \multicolumn{2}{|l|}{ Hole 530A (Cont.) } & \multicolumn{2}{|l|}{ Hole 530A (Cont.) } \\
\hline Cores 1 to 2 & A & $59-2,0-70$ & C-1 & $84-4$, & C-3 \\
\hline \multirow{2}{*}{\multicolumn{2}{|c|}{ Hole 530A }} & $59-2,70-150$ & C-3 & Cores 85 to 86 & $C-1$ \\
\hline & & 60-1, & C-1 & 87 -Sections 1 to 2 & C-1 \\
\hline Cores 1 to 34 & A & $60-2,0-35$ & C-3 & $87-3$ & $C-2$ \\
\hline Cores 35 to 36 & C-3 & $60-2,35-80$ & C-1 & 87-4, & C-1 \\
\hline $37-1$ & $\mathrm{C}-1$ & $60-2,80-150$ & C-3 & $87-5$ & $C-2$ \\
\hline $38-1$ & $C-1$ & 61-1, & C-1 & $88-1,0-30$ & $C-3$ \\
\hline $38-2$ & C-3 & 61 -Sections 2 to 4 & C-3(?) & $88-1,30-150$ & C-1 \\
\hline $39-1$ & C-1(?) & $61-5$ & $C-1$ & $88-2,-$ & $C-1$ \\
\hline $39-2$ & $\mathrm{C}-3$ & 62 -Sections 1 to 2 , & $C-1$ & $88-3,0-35$ & $C-1$ \\
\hline $40-1$ & $C-1$ & $62-3,0-50$ & $\mathrm{C}-1$ & $88-3,35-45$ & C-3 \\
\hline $40-2,0-40$ & C-1 & $62-3,50-85$ & C-3(?) & $88-3,45-150$ & $C-1$ \\
\hline $40-2,40-150$ & C-2 & $62-3,85-90$ & C-1 & $89-1,0-33$ & C-1 \\
\hline 40 - Sections 3 to 4 & $C-3$ & $62-3,90-150$ & C-3 & $89-1,33-82$ & C-3 \\
\hline 41 & C-1 & $62-4$, & C-4 & $89-1,82-104$ & C-1 \\
\hline $42-1,0-90$ & C-1 & $63-1,0-105$ & C-1 & $89-1,104-150$ & C-3 \\
\hline $42-1,90-150$ & C-3 & $63-1,105-150$ & C-3 & 89 -Sections 2 to 3 & C-2(?) \\
\hline 42- Sections 2 to 3 & $C-3$ & $63-2,0-20$ & $\mathrm{C}-1$ & $89-4,0-76$ & $C-3$ \\
\hline $43-1,0-80$ & C-1 & $63-2,20-38$ & C-4 & $89-4,76-150$ & $C-1$ \\
\hline $43-1,80-150$ & C-3 & $63-2,38-46$ & $C-1$ & $89-5$, & $C-3$ \\
\hline $43-2$ & C-2 & $63-2,46-62$ & $C-4$ & $89-6,0-25$ & $C-1$ \\
\hline $44-1$ & C-1 & $63-2,62-150$ & $C-1$ & $89-6,25-33$ & C-3 \\
\hline $44-2$ & C-2 & $63-3,0-83$ & C-1 & $89-6,33-98$ & C-1 \\
\hline Cores 45 to 46 & C-1 & $63-3,83-110$ & C-3 & $89-6,98-120$ & C-3 \\
\hline Cores 47 to 48 & $C-3$ & $63-3,110-150$ & C-1 & $89-6,120-150$ & C-1 \\
\hline 49 & C-1 & 64-1, & C-1 & $90-1,0-50$ & C-1 \\
\hline $50-1,0-40$ & C-1 & $64-2,0-32$ & C-1 & $90-1,50-150$ & $\mathrm{C}-3$ \\
\hline $50-1,40-55$ & C-3 & $64-2,32-55$ & $C-3$ & $90-2$ & $C-3$ \\
\hline $50-1,55-65$ & C-1 & $64-2,55-85$ & $C-1$ & 90-3, & C-1(?) \\
\hline $50-1,65-130$ & C-3 & $64-2,85-135$ & C-3 & $91-1,0-70$ & C-2(?) \\
\hline $50-1,130-150$ & C-1 & $64-2,135-150$ & C-1 & $91-1,70-135$ & C-1 \\
\hline $50-2,0-30$ & $C-3$ & $64-3$ to 4 & C-1 & $91-1,135-150$ & $C-4$ \\
\hline $50-2,30-95$ & C-1 & 67-Sections 1 (?) to 2 & C-1 & $91-2,-$ & C-1 \\
\hline $50-2,95-107$ & C-3 & $67-3,0-59$ & C-1 & $91-3,0-70$ & C-1 \\
\hline $50-2,107-118$ & C-1 & $67-3,59-70$ & C-3 & $91-3,70-102$ & $C-4$ \\
\hline $50-2,118-150$ & C-3 & $67-3,70-85$ & C-1 & $91-3,102-150$ & C-1 \\
\hline $50-3,0-50$ & C-1 & $67-3,85-109$ & C-3 & $91-4$ & C-1 \\
\hline $50-3,50-60$ & C-3 & $67-3,109-150$ & C-1 & 93 & C-1 \\
\hline $50-3,60-150$ & $C-1$ & $67-4$ & C-1 & $94-1,0-60$ & C-1(?) \\
\hline $50-4,0-20$ & C-3 & Cores 68 to 69 & C-1 & $94-1,60-105$ & $\mathrm{C}-1$ \\
\hline $50-4,20-30$ & C-1 & 70-1, & C-1 & $94-1,105-125$ & $C-1(?)$ \\
\hline $50-4,30-150$ & C-3 & $70-2,0-90$ & C-1 & $94-1,125-150$ & $C-1$ \\
\hline $51-1,0-120$ & C-1 & $70-2,90-130$ & $\mathrm{C}-3$ & $94-2$ & $C-1$ \\
\hline $51-1,120-130$ & C- -4 & $70-2,130-150$ & $C-1$ & 95- & $C-1$ \\
\hline $51-1,130-150$ & C-1 & 70-3, & $\mathrm{C}-1$ & $96-1,0-30$ & C-1 \\
\hline $51-2,0-8$ & C-2 & $70-4,0-30$ & $\mathrm{C}-1$ & $96-1,30-50$ & C-1(?) \\
\hline $51-2,8-15$ & C-1 & $70-4,30-150$ & C-3 & $96-1,50-150$ & C-1 \\
\hline $51-2,15-150$ & C- -4 & Cores 71 to 74 & $C-1$ & 96. & $C-1$ \\
\hline $51-3,0-67$ & C -4 & $75-1$ to 4 & $C-1$ & 97-Sections 1 to 3 & C-1 \\
\hline $51-3,67-75$ & C-2 & $75-5$ & C-3 & $97-4,0-15$ & $C-1$ \\
\hline $51-3,75-150$ & C- 4 & $76-1$ & $C-1$ & $97-4,15-25$ & $C-3$ \\
\hline $51-4,0-45$ & $C-4$ & $76-2,0-35$ & C- 4 & $97-4,25-40$ & $C-1$ \\
\hline $51-4,45-112$ & C-2 & $76-2,35-73$ & C-1 & $97-4,40-50$ & C-3 \\
\hline $51-4,112-127$ & C-4 & $76-2,73-90$ & C-4 & $97-4,50-150$ & $C-2$ \\
\hline $51-4,127-150$ & $\mathrm{C}-2$ & $76-2,90-150$ & C-1 & $98-1,0-70$ & $C-1$ \\
\hline $51-5,0-10$ & C-3 & $76-3$ to 5 & $C-1$ & $98-1,70-80$ & $C-3$ \\
\hline $51-5,10-32$ & C-2 & $77-1$ & $C-1$ & $98-1,80-150$ & C-1 \\
\hline $51-5,32-36$ & $C-4$ & $77-2$ & C-4(?) & 98 -Sections 2 to 3 & C-1 \\
\hline $51-5,36-66$ & C-2 & $77-3$ to 4 & C-1 & Cores 99 to 103 & $C-1$ \\
\hline $51-5,66-75$ & $C-4$ & $77-5,0-50$ & $C-1$ & $104-1,0-25$ & C-1(?) \\
\hline $51-5,75-110$ & C-2 & $77-5,50-77$ & C-3 & $104-1,25-150$ & $C-1$ \\
\hline $51-5,110-150$ & $C-4$ & $77-5,77-150$ & C-1 & $104-2,0-125$ & $C-1$ \\
\hline $52-$ & C-1(?) & $77-6$ & C-1 & $104-2,125-136$ & $C-4$ \\
\hline $53-1,0-110$ & $\mathrm{C}-1$ & Cores 78 to 80 & C-1 & $104-2,136-150$ & $C-1$ \\
\hline $53-1,110-130$ & $C-3$ & $81-1$ & $C-1$ & $104-3$ to 6 & $C-1$ \\
\hline $53-1,130-150$ & C-1 & $81-2,0-15$ & C-3 & Cores 105 to 108 & $C-1$ \\
\hline $53-2$ & C-3 & $81-2,15-38$ & C-1 & & \\
\hline Cores 54 to 55 & C-1 & $81-2,38-150$ & C-3 & Hole 530B & \\
\hline $56-1$ & C-1 & $81-3$ & $\mathrm{C}-3$ & Cores 1 to 48 & A \\
\hline $56-2,0-63$ & C-1 & $82-1,0-45$ & $C-1$ & Cores 10040 & A \\
\hline $56-2,63-80$ & C-3 & $82-1,45-61$ & C-3 & Hole $530 \mathrm{X}$ & \\
\hline $56-2,80-150$ & $C-1$ & $82-1,61-150$ & C-3 & & \\
\hline Cores 57 to 58 & C-1 & 82 -Sections 2 to 5 & C-1 & Cores 1 to 2 & A \\
\hline $59-1$ & C-1 & $83-$ & C-1 & Hole 532 & A \\
\hline & & 84-1, & C-1 & Hole 532A & A \\
\hline & & 84 -Sections 2 to 3 & C-2 & Hole 532B & A \\
\hline
\end{tabular}


Table 10. Apparent attenuation coefficients determined from the 6.61 $\mathrm{cm}$ and $2.54 \mathrm{~cm}$ aluminum standards processed 25 July 1980

\begin{tabular}{cc}
\hline $\begin{array}{c}\text { Aluminum } \\
2.54 \mathrm{~cm} \\
\left(\mathrm{~cm}^{2} / \mathrm{g}\right)\end{array}$ & $\begin{array}{c}\text { Aluminum } \\
6.61 \mathrm{~cm} \\
\left(\mathrm{~cm}^{2} / \mathrm{g}\right)\end{array}$ \\
\hline 0.10032 & 0.10102 \\
0.10076 & 0.10155 \\
0.10015 & 0.10140 \\
0.10060 & 0.10062 \\
0.10029 & 0.10119 \\
0.10069 & 0.10094 \\
0.10125 & 0.10113 \\
0.10079 & 0.10128 \\
0.10023 & 0.10123 \\
0.10056 & 0.10151 \\
$\Sigma=1.00564$ & $\Sigma=1.01187$ \\
$\mathrm{M}=0.100564$ & $\mathrm{M}=0.101187$ \\
STD $=0.000325$ & STD $=0.0002800$ \\
no. $=10$ & no. $=10$ \\
\hline
\end{tabular}

Note: Apparent quartz attenuation coefficient $=\left(\right.$ ln $\left.I_{O} / I\right) / d\left(2.60 \mathrm{~g} / \mathrm{cm}^{3}\right)$ where $I_{O}=$ gamma count through air, $I=$ gamma count aluminum standard, and $d=$ thickness of standard $(2.54 \mathrm{~cm}$ or $6.61 \mathrm{~cm})$.

Table 11. Apparent attenuation coefficients determined from the $6.61 \mathrm{~cm}$ and $2.54 \mathrm{~cm}$ aluminum standards processed 25 August 1980.

\begin{tabular}{|c|c|}
\hline $\begin{array}{l}\text { Aluminum } \\
2.54 \mathrm{~cm} \\
\left(\mathrm{~cm}^{2} / \mathrm{g}\right)\end{array}$ & $\begin{array}{l}\text { Aluminum } \\
6.61 \mathrm{~cm} \\
\left(\mathrm{~cm}^{2} / \mathrm{g}\right)\end{array}$ \\
\hline 0.10081 & 0.10140 \\
\hline 0.10050 & 0.10146 \\
\hline 0.10019 & 0.10099 \\
\hline 0.10051 & 0.10149 \\
\hline 0.10069 & 0.10136 \\
\hline 0.10046 & 0.10111 \\
\hline 0.10053 & 0.10098 \\
\hline 0.10048 & 0.10159 \\
\hline 0.10048 & 0.10139 \\
\hline 0.10092 & 0.10146 \\
\hline$\Sigma=1.00557$ & $\Sigma=1.01323$ \\
\hline $\mathrm{M}=0.100557$ & $\mathrm{M}=0.101323$ \\
\hline $\mathrm{STD}=0.0002043$ & STD $=0.0002166$ \\
\hline $\begin{array}{l}\text { Avg. for August and July } 2.54 \mathrm{~cm} \\
\text { Al standards: }\end{array}$ & $\begin{array}{l}\text { Avg. for July and August } 6.61 \mathrm{~cm} \\
\text { Al standards: }\end{array}$ \\
\hline$=0.100557 \mathrm{~cm}^{2} / \mathrm{g}+0.100564 \mathrm{~cm}^{2} / \mathrm{g}$ & $0.101323 \mathrm{~cm}^{2} / \mathrm{g}+0.101187 \mathrm{~cm}^{2} / \mathrm{g}$ \\
\hline 2 & 2 \\
\hline$=0.10056 \mathrm{~cm}^{2} / \mathrm{g}$ & $=0.10126 \mathrm{~cm}^{2} / \mathrm{g}$ \\
\hline
\end{tabular}

(These values were used in the computer program calculations, discussed elsewhere.)

Note: Apparent quartz attenuation coefficient $=\left(\ell n I_{O} / I\right) / d\left(2.60 \mathrm{~g} / \mathrm{cm}^{3}\right)$

where $I_{0}=$ gamma count through air, $1=$ gamma count aluminum $d=$ thickness of standard $(2.54 \mathrm{~cm}$ or $6.61 \mathrm{~cm})$.

Wet-bulk density is the ratio of the "mass of a wetsaturated geologic sample" to its "volume," in units of grams per cubic $\mathrm{cm}\left(\mathrm{g} / \mathrm{cm}^{3}\right)$. Wet-water content is the ratio of the "weight of seawater in a geologic sample" to the "weight of the wet-saturated geologic sample," expressed as a percentage. Porosity is the ratio of "the volume of pore space in a geologic sample" to the "volume of the wet-saturated sample," reported as a percentage.
On board the ship, the 10 to $30 \mathrm{~g}$ samples were weighed in air and weighed after submersion in water, using an Ohaus Centrogram triple beam $(311 \mathrm{~g})$ balance, then dried in the oven at $105^{\circ} \mathrm{C}$ for 24 hours, cooled in a desiccator for at least 2 hours, and then reweighed. Salt corrections for $35 \mathrm{ppt}$ salinities (as described in Boyce, 1976) are applied to the wet-water content and porosity. The technique is discussed in Rocker (1974).

The reproducibility of method in terms of wet-bulk density is $\pm 0.005 \mathrm{~g} / \mathrm{cm}^{3}$, which is about $\pm 0.2 \%$ (absolute) precision for the porosity and water content values.

1) Wet-bulk density (with pan weights removed) is equal to the weight of the saturated sample in air divided by its volume:

$$
\text { Volume }=\frac{\text { weight in air }- \text { weight in water }}{1.00 \mathrm{~g} / \mathrm{cm}^{3}}
$$

2) Wet-water content (with pan weights removed) without salt correction equals:

$$
\frac{\text { weight of evaporated } \mathrm{H}_{2} \mathrm{O}}{\text { weight of saturated sample }} \text {, }
$$

where the weight of evaporated water equals the weight of the saturated sample minus weight of dried sample.

Wet-water content (salt corrected) equals:

$$
\%=\left[\frac{\frac{\text { (weight evaporated water) }}{(0.965)}}{\text { weight saturated sample }}\right] \times 100,
$$

where the weight of seawater is the weight of evaporated water divided by 0.965 .

3) Porosity without salt correction (with pan weights removed) equals:

$$
\%=(100)\left[\frac{\frac{\text { (weight evaporated water) }}{1.00 \mathrm{~g} / \mathrm{cm}^{3}}}{\text { (volume of saturated sample) }}\right],
$$

where sample volume equals weight saturated sample in air minus weight saturated sample in water, and 1.00 $\mathrm{g} / \mathrm{cm}^{3}$ is the density of water.

Salt corrected porosity equals:

$$
\underline{\text { (weight evaporated water } \div 0.965 \text { ) }}
$$

$$
\%=(100) \frac{1.0245 \mathrm{~g} / \mathrm{cm}^{3}}{\text { (volume of saturated sample) }} \text {, }
$$

where $1.0245 \mathrm{~g} / \mathrm{cm}^{3}$ is the fluid density of the seawater salt, and weight of seawater is (weight evaporated water) divided by 0.965 .

Many of the really soft samples were processed by the cylinder technique method on shore at DSDP headquarters. This technique uses a cylinder $(\sim 3 \mathrm{~cm}$ radius, $2 \mathrm{~cm}$ 
height, and $\sim 1 \mathrm{~mm}$ thick with beveled edges), which is inserted into the soft sediment; it is then cut from the core, and the excess sediment is carefully cut off the cylinder. Then plastic plates are placed on the top and bottom of the cylinder. Rubber bands are placed around the plastic plates, and the same is placed under seawater and shipped to DSDP shore laboratory. There the preweighed cylinders and plates plus the saturated sample are weighed and the cylinder and plate are put in an oven at $105^{\circ} \mathrm{C}$ for 24 hours, then placed in a desiccator to cool for at least 2 hours before being reweighed. Wetwater content, wet-bulk density, and porosity are calculated. The volume used in wet-bulk density and porosity measurements is that of the cylinders.

Salt corrections are applied as has been discussed. Precision is about $\pm 0.5 \%$.

One advantage of the cylinder technique is that the cylinder technique sample can also be processed by the GRAPE 2-minute count method.

This is done as discussed for the GRAPE 2-minute wet-bulk density, but substituting the gamma-ray count through the two plastic plates for the air count. Then the cylinder with sample and the two plastic plates are counted for 2 minutes through the cylinder axis and through the two plastic plates. A 2-minute GRAPE wetbulk density can be calculated.

\section{GEARHART-OWEN WELL LOG EQUIPMENT USED DURING LEG 75}

\section{Introduction}

During DSDP Leg 75, we used Gearhart-Owen Industries wire-line well logging tools. Attempts were made to use the following suite of Gearhart-Owen logging tools in Hole 530A:

1) Gamma Ray (GR) and Neutron (thermal neutron) Log; single detector, unpositioned, qualitative, and 3.65 $\mathrm{cm}$ in diameter. This tool was run in the pipe and bottom-hole assembly from 0 to $1050 \mathrm{~m}$ in Hole 530A. Logging speed was $9.14 \mathrm{~m}$ per minute with a time constant of $3 \mathrm{~s}$.

(Successful)

2) Absolute and Differential Temperature $\log ^{3}$ (thermocouple), $3.65 \mathrm{~cm}$ in diameter $\left( \pm 0.05^{\circ} \mathrm{C}\right)$; plus Density Log (borehole compensated) (CDL), $6.99 \mathrm{~cm}$ in diameter; caliper; and GR. Logging speed was $9.14 \mathrm{~m}$ per minute.

(Unsuccessful)

3) Sonic Log (borehole compensated system), centered in hole, $9.21 \mathrm{~cm}$ diameter, caliper, and Gamma-Ray Log (GR). The tool was run from $628 \mathrm{~m}$ to $940 \mathrm{~cm}$ in the bare hole at Hole 530A. Logging speed was $18.29 \mathrm{~m}$ per minute with a time constant of 3 .

4) Induction $\mathrm{Log}$ and $16-\mathrm{Inch}(40 \mathrm{~cm})$ Normal Resistivity, unpositioned in hole, $9.21 \mathrm{~cm}$ in diameter, and GR. The tool was run from 628 to $855 \mathrm{~m}$ in the bare hole at $530 \mathrm{~A}$. Logging speed is $9.14 \mathrm{~m}(?)$ per minute and with a 3-s time constant.

(Successful)

\footnotetext{
${ }^{3}$ These tools could not be lowered past a bridge in the hole. This is not "absolute temperature" (e.g., Kelvin) in the scientific sense, but the formal name of the tool. Temperature measured while the tool was lowered into the hole.
}

5) Deep Laterolog (LL-3), $8.9 \mathrm{~cm}$ diameter (poor data) and Neutron Log (thermal neutron, single detector and unpositioned, therefore, qualitative); GR. The tool was run from 628 to $855 \mathrm{~m}$ in the bare hole at Hole 530A. Logging speed was $9.14 \mathrm{~m}$ per minute with a time constant of $3 \mathrm{~s}$.

(Partially successful)

6) Absolute and Differential Temperature Log. The tool was run from 628 to $855 \mathrm{~m}$ in the bare hole at Hole 530A. Logging speed was $9.14 \mathrm{~m}$ per minute, and the temperature was measured while the tool progressed down the hole.

(Successful)

The GR tool is run with each logging run for stratigraphic control. As an example, the GR also allows the density and velocity on two different logging runs to be correlated, since the depths are not accurate enough.

In general, when interpreting any of these logs one should consult Lynch (1962) and a Gearhart-Owen manual to determine what precautions and data corrections are necessary and to find the proper charts in various manuals and perform any needed corrections.

These data are available at various scales in analog plots and on magnetic tape.

See site chapter for discussion of hole conditions, casing, and drill pipe.

\section{Natural Gamma Radiation}

\section{Various Diameter Gamma-Ray Logs}

In general the GR log has a scintillation detector which is $15.2 \mathrm{~cm}$ long. The GR data are in American Petroleum Institute (API) units (American Petroleum Institute, 1959). The GR detects natural gamma radiation emitted primarily from potassium, thorium series, and uranium-radium series contained in the formation. Generally carbonate and sandstone, without potassium feldspars, emit very little natural gamma radiation compared to clay- and shale-type formations, which absorb radioactive isotopes as ions. Therefore, the GR is primarily used to distinguish: clayey shale and nonclayey (nonshale) formations. The GR tool, interpretation problems, and data characteristics, such as time constant and logging speed, are discussed in Lynch (1962) and Kokesh (1951).

\section{Sound Velocity}

During Leg 75, we ran the Sonic Log (borehole compensated system). This tool measures compressionalsound velocity in units of $\mu \mathrm{s} / \mathrm{ft}$. $(30.5 \mathrm{~cm})$, which is converted to $\mathrm{km} / \mathrm{s}$ for publication by the DSDP computer group. The basic principle of the tool and basic data-interpretation characteristics are described in Kokesh et al. (1965) and Morris et al. (1963). In addition, "noise" and "cycle skipping" and precautions in data interpretation are discussed in Lynch (1962). On the BHC tool, the two receivers were separated by $61 \mathrm{~cm}$ (vertical resolution), and the distance from the transmitter to the first receiver is $91.4 \mathrm{~cm}$.

The tool had a centering-device-caliper; thus, the tool may have too much stand-off from the side of the hole to be accurate (Lynch, 1962) for the low formation velocities involved. Since the compensated sonic log is es- 
sentially a "two-layer seismic refraction experiment," and given the centralized geometry of the tool, when the formation's velocity approaches that of the fluid in the hole, velocities below 1.7 to 1.8 are probably not measurable. Velocities below 1.7 to $1.8 \mathrm{~km} / \mathrm{s}$ are severely affected by tool stand-off (Fig. 1A) (distance of transmitters and receivers from borehole wall). For example, Figure 1B shows that the diameter of the hole must be less than that of the maximum diameter if the corresponding formation velocity is to be measured.

This diagram clearly indicates that we cannot measure a formation velocity of less than 1.67 where the hole is $>12$ inches $(30 \mathrm{~cm})$ in diameter. Any velocities less than 1.67 are partially or completely those of the fluid in the borehole.

\section{Formation Wet-Bulk Density}

Leg 75 used the Density (borehole compensated) Log. The source and two receivers are held against the side of the hole by a motorized eccentralizer, which also acts as a caliper. The density log is calibrated for density in limestone matrix, with fresh water in the pores.

The tool measures an approximate wet-bulk density using a gamma-ray back-scattering technique. Wet-bulk density is the ratio of the "mass of wet-saturated (if in situ gas is not present) formation" to its "volume," expressed as grams per cubic centimeters. The general principles of this technique, similar logging tools and their interpretation characteristics, assumptions, and precautions are discussed in Wahl et al. (1964) and Sherman and Locke (1975). Additional discussion of general principles, etc., are also in Baker (1957) and Lynch (1962). Vertical resolution and penetration are about $30 \mathrm{~cm}$ depending on formation density and logging speed. ${ }^{4}$

${ }^{4}$ The GR on the density log is offset by about $0.30 \mathrm{~cm}$ higher than the density reading.

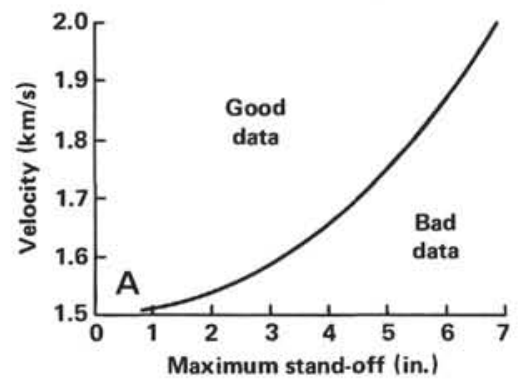

Lynch (1952) p. 275: $S=\left[\frac{1}{2}\left(\frac{1-\beta}{1+\beta}\right)^{1 / 2}\right]$, Where: $S=$ Standoff of sonic transmitter and receiver

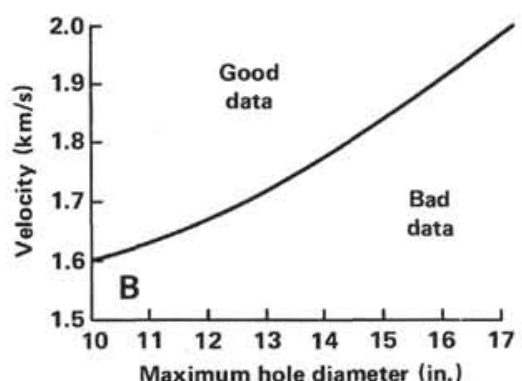

1 = Distance from transmitter to first receiver

$\beta=$ Ratio of hole fluid velocity to formation velocity

Assumes compensated sonic tool with $1=3$ feet and tool diameter of 3.5 inches.

Figure 1. A. Maximum possible tool stand-off if the corresponding formation velocity is to be measured. B. Maximum possible hole diameter in measuring the corresponding formation velocity.

\section{Formation Porosity}

\section{Neutron Tool}

The Neutron Tool has a single detector; it is not positioned in the hole (i.e., free) and thus it is a qualitative tool. It emits thermal neutrons that are primarily (but not completely, e.g., $\mathrm{Cl}$ ) attenuated by collisions with $\mathrm{H}^{+}$protons (same mass as neutron) in the pore water. With the proper matrix correction, the tool is a qualitative indicator of porosity. The tool's principal assumptions and precautions are discussed in Tittle (1961) and Lynch (1962). The depth of investigation and vertical resolution is on the order of $33 \mathrm{~cm}$, depending on logging speed, porosity, and type of formation.

\section{Electric Logging Tools}

The Induction Log (six coil system, 20,000 cycles/s) has a $100-\mathrm{cm}$ vertical resolution, and about $50 \%$ of the signal has an approximate 155 -cm radial depth of investigation; the 16 -inch $(40.6 \mathrm{~cm})$ normal tool has an approximate $40.6-\mathrm{cm}$ vertical resolution and radial depth of investigation. The induction tool is designed primarily to measure electrical conductivity accurately in high porosity sediment and rock (with resistivity $<100 \mathrm{ohm}-$ $\mathrm{m}$ ). The Guard Log (Laterolog-3) is a focused electrical resistivity tool designed with a $15-\mathrm{cm}$ vertical resolution, and $50 \%$ of the signal has an approximate $65 \mathrm{~cm}$ of radial penetration. It is designed to measured accurately electrical resistivity of hard rocks (such as basalt with $>100 \mathrm{ohm}-\mathrm{m}$ resistivity). All of these electrical logging tools are affected by the geometry and resistivity of the formations and borehole. Therefore, the caliper data should be used from the density log to properly correct these electric logs to true formation resistivities. See Lynch (1962), Doll (1949, 1951), Moran and Kunz (1962), Tixier et al. (1959), and Keller and Frischknecht (1966) for detailed discussions and precautions.

\section{Temperature Log}

On Leg 75 we used the Differential and Absolute Temperature $\mathrm{Log}$, which is $4.65 \mathrm{~cm}$ in diameter and has a thermocouple which records temperature continuously versus depth. Its precision is better than $\pm 0.05^{\circ} \mathrm{C}$ with an accuracy of \pm 2 or $3 \%$ of the calibrated range. The tool has a platinum tip resistance thermometer. Temperature tools in general are briefly described in Lynch (1962).

The differential tool compares the temperatures being immediately measured with an earlier measured temperature (measured with same element), but stored in a memory bank from which the value is recalled after a given period of time. The difference in these two temperature measurements is plotted versus depth.

\section{Uyeda Temperature Probe}

The Uyeda Temperature Probe has a long $(\sim 30 \mathrm{~cm})$ and thick $(\sim 3 \mathrm{~cm})$ metal probe that is inserted into the bottom of the drill hole via attachments through the drill bit. In the $\sim 3-\mathrm{cm}$ diameter metal tip is a thin $\sim 0.5-\mathrm{cm}$ thick thermistor. On Leg 75 this tool was adjusted to automatically record the temperature every 2 minutes. With this tool it is possible to record 128 data points 
over a total period of 256 minutes. Therefore, the data are in the form of time versus temperature. The tool is lowered through the pipe, passing the ocean's water column and passing the hole while recording temperature (every 2 minutes) on the way down. In addition, while the probe is inserted into the bottom of the hole (where it remains until temperature equilibrium has obtained maximum temperature after $\sim 20$ minutes) and then is removed and pulled out of the hole, it is still recording temperature every two minutes. The water temperature of the ocean bottom is measured on the way up (the tool stops at $\sim 20 \mathrm{~m}$ above seafloor for $\sim 10 \mathrm{~min}$.). By plotting "time versus temperature" we can recognize the temperature measurements in the ocean's water column, the sediment at the bottom of the hole, and the ocean bottom water $20 \mathrm{~m}$ above the seafloor.

The temperature tool has a theoretical precision and accuracy of $\pm 0.05^{\circ} \mathrm{C}$.

We attempted several temperature measurements, the results of which are in the site chapter.

\section{REFERENCES}

American Petroleum Institute, 1959. Recommended Practice for Standard Calibration and Form for Nuclear Logs. (API RP 33, Sept.).

Baker, P. E., 1957. Density logging with gamma rays. Trans. AIME, 210:289-294.

Boyce, R. E., 1973. Appendix I. Physical property methods. In Edgar, N. T., Saunders, J. B., et al., Init. Repts. DSDP, 15: Washington (U.S. Govt. Printing Office), 1115-1128.

1976. Definitions and laboratory techniques of the compressional sound velocity parameters and wet-water content, wetbulk density, and porosity parameters by gravimetric and gamma ray attenuation techniques. In Schlanger, S. O., Jackson, E. D., et al., Init. Repts. DSDP, 33: Washington (U.S. Govt. Printing Office), 1115-1128.

1977. Deep Sea Drilling Project procedures for shear strength measurement of clayey sediment using modified Wykeham Farrance laboratory vane apparatus. In Barker, P. F., Dalziel, I. W. D., et al., Init. Repts. DSDP, 36: Washington (U.S. Govt. Printing Office), 1059-1068.

Clark, S. P., Jr., 1966. Thermal conductivity. In Clark, S. P., Jr. (Ed.), Handbook of Physical Constants (Geol. Soc. Am. Mem.), 97:459-482.
Doll, H. G., 1949. Introduction of induction logging and application to logging of wells drilled with oil base mud. Trans. AIME, 186: 148-164.

1951. The Laterolog: A new resistivity logging method with electrodes using an automatic focusing system. Trans. AIME, 192: 305-316.

Evans, H. B., 1965. GRAPE-A device for continuous determination of material density and porosity. Trans. SPWIA Logging Symp. (6th Ann., Dallas, Texas), 2:B1-B25.

Keller, G. V., and Frischknecht, F. C., 1966. Electrical Methods in Geophysical Prospecting: New York (Pergamon Press).

Kokesh, F. P., 1951. Gamma-ray logging. Oil Gas J., 50(12):284-290.

Kokesh, F. P., Schwartz, R. J., Wall, W. B., and Morris, R. L., 1965. A new approach to sonic logging and other acoustic measurements. J. Petrol. Tech., 17:282-286.

Lynch, E. J., 1962. Formation Evaluation: New York (Harper \& Row).

Mattaboni, P., and Schreiber, E., 1967. Method of pulse transmission measurements for determining sound velocities. J. Geophys. Res., $72: 5160$.

Moran, J. H., and Kunz, K. S., 1962. Basic theory of induction logging and application to study of two-coil sondes. Geophysics, 27: 829-858.

Morris, R. L., Grine, D. R., and Arkfeld, T. E., 1963. The use of compressional and shear strength amplitudes for the location of fractures. Soc. Petrol. Eng. AIME (New Orleans, 1963). Pap. no. SPE 723:1-13.

Rocker, K., 1974. Physical properties and measurements and test procedures for Leg 27. In Veevers, J. J., Heirtzler, J. R., et al., Init. Repts. DSDP, 27: Washington (U.S. Govt. Printing Office), 433-444.

Sherman, H., and Locke, S., 1975. Effect of porosity on depth of investigation of neutron and density sondes. Soc. Petrol. Eng. AIME (Dallas, 1975). Pap. no. SPE 5510:1-12.

Tittle, C. W., 1961. Theory of neutrons logging. Geophysics, 26:27-29.

Tixier, M. P., Alger, R. P., and Tanghy, D. R., 1959. New developments in induction and sonic logging. Soc. Petrol. Eng. AIME (Dallas, 1959). Pap. no. 1300-G:1-18.

Von Herzen, R. P., and Maxwell, A. E., 1959. The measurement of thermal conductivity of deep-sea sediments by a needle-probe method. J. Geophys. Res., 64:1557.

Wahl, J. S., Tittman, J., and Johnstone, C. W., 1964. The dual spacing Formation Density Log. J. Petrol. Tech., 16:1411-1416.

Date of Initial Receipt: August 27, 1981 